\title{
Azotlu Gübrelemenin Bazı Tritikale Genotiplerinde Azot Kullanım Özelliklerine Etkisi
}

\author{
Mehmet Ali BOZKURT ${ }^{1} \quad$ K. Mesut ÇIMRIN ${ }^{\dagger} \quad$ Nazım ŞEKEROĞLU ${ }^{2}$ \\ Geliş Tarihi: 12.02 .2001
}

\begin{abstract}
Özet: Bu araştirma Van koșullarında artan azotlu gübre düzeylerinin $(0,4,8,12$ ve $16 \mathrm{~kg} \mathrm{~N} / \mathrm{da})$ dört tritikale genotipinde (X Triticosecale Wittmack) azot içeriğine, azot alımına, azot kullanım etkinliğine ve azot hasat indeksine etkilerini belirleyebilmek için yourutolmuştar. Araștirma sonuçlarina göre, azotlu gübreleme ile sap ve tanede azot içeriği ile alımı önemli duzeyde artarken, azot kullanım etkinliği ve azot hasat indeksi azotlu gübreleme ile azalmıștır. Azot içeriği ve alımı $12 \mathrm{~kg} \mathrm{~N} / \mathrm{da}$ dôzeyinde en yüksek değere ulaşmışır. Azotlu gübreleme lie azot kullanım etkinliği 46.4' ten, 37. $0^{\prime}$ a, azot hasat indeksi $76.0^{\prime}$ dan $68.4^{\prime}$ e gerilemiștir. Tane azot içeriği hariç, incelenen diğer ozelliklere tritikale genotiplerinin etkisi önemill bulunmamıştır. En dâşük tane azot içeriği 9 nolu tritikale genotipinde belirlenmiştir. Azot kullanım etkinliği ile tane verimi arasında, kontrol ve orta düzeyde azot uygularnalarında (4 ve $8 \mathrm{~kg} \mathrm{~N} / \mathrm{da}$ ) çok önemli ilişkiler belirlenmiş ancak, bu iliş̧inin derecesi yŭkssek azot dozlarında (12 ve $16 \mathrm{~kg} \mathrm{~N} / \mathrm{da}$ ) azalmıştır. Azotlu gübrenin artan dozlarında azot kullanım etkinliğinin düștuğă ve azot kullanım etkinliği ile tane verimi arasındaki ilișkinin zayıfladığı belirlenmiştir. Bu sonuçlar, tritikalede azot kullanım özellikjerinin azotlu gübreleme le önemli dâzeyde değiştiğini göstermehtedir.
\end{abstract}

Anahtar Kelimeler: Tritikale, azot, gübre, azot kuilanım özellikleri

\section{The Effect of Nitrogenous Fertilization on Nitrogen Use Properties in Some Triticale Genotypes}

\begin{abstract}
In this research, the effects of nitrogen fertilizer doses in four triticale genotypes ( $X$ Triticosecale Wittmack) on nitrogen concentration, nitrogen uptake, nitrogen use efficiency and nitrogen harvest index were determined in Van ecological conditions. According to experiment results, nitrogen use efficiency and nitrogen harvest index decreased with nitrogen fertilization while nitrogen concentration, nitrogen uptake of straw and grain increased with nitrogen fertilization. The highest nitrogen concentration and uptake were obtained at $12 \mathrm{~kg} \mathrm{~N} / \mathrm{da}$ nitrogen dose. With nitrogen fertilization, nitrogen use efficiency and nitrogen harvest index decreased from 46.4 to 37.0 and from 76.0 to 68.4 , respectively. On the investigated all other characters, genotypes effect was not important except grain nitrogen concentration. Grain nitrogen concentration was found the lowest at number 9 genotype. The relationships between nitrogen use efficiency and grain yield were found very important at control $\left(\mathrm{N}_{0}\right)$ and middle level nitrogen doses $(4$ and 8 $\mathrm{kg} \mathrm{N} / \mathrm{da}$ ) but degree of this relationship decreased at high level nitrogen doses (12 and $16 \mathrm{~kg} N / \mathrm{da}$ ). Nitrogen use efficiency, and relationship between nitrogen use efficiency and grain yield decreased with increasing nitrogen doses. This results suggest that nitrogen use properties of triticale can changed significantly with nitrogenous fertilization.
\end{abstract}

Key Words: Triticale, nitrogen, fertilizer, nitrogen use properties

\section{Giriş}

Tritikale ( $X$ Triticosecale Wittmack) buğday lle çavdarın melezlenmesinden elde edilen, buğdayın yüksek tane verimi ile çavdarın soğuğa, kuraklığa ve bazı hastalıklara dayanıkılığını yapısında birleştiren yapay bir tahıldır. Tritikale olumsuz toprak koşullarına iyi adapte olduğu gibi, yatma, külleme ve pas gibi hastalıklara dayanıklıdır. Bunların yanında tritikale, yŭksek protein ve verimlilik özellikleri ile de büyük önem kazanmaktadir (Yağbasanlar ve Ülger 1989).

Yăksek verimli tahıl çeşitlerinin fazla azotlu gübre uygulamasina gerek duymaları ve azotlu göbrelerin youksek maliyetinden dolayı, çeşitlerin azot alım ve kullanım etkinliğinin iyileşmesi ıslah proğramlarındaki onemli amaçlardan biridir. Tahıllarda azot kullanım etkinliğinin genotipe bağlı olarak önemli düzeyde değiştiği pek çok araştırıcı tarafından bildirilmiştir (Isfan 1990, Tilman ve ark. 1991). Isfan ve ark. (1991)'in 12 tritikale genotipi ile iki ayrı azot dozunda yaptıkları araștırmada tane verimi ve azot kullanım etkinliğinin genotiplere göre onnemli düzeyde değiștiğini ve tane verimi ile azot kullanımı arasında pozitif ve önemli düzeyde ilişki olduğunu belirlemişlerdir.

Genetik seleksiyon çalıșmaları genellikle yôksek azot düzeylerinde yürütúldağa için, azot alımı ve kullanımı bakımından genotipler arası farklar gizlenebilmektedir (Kampart ve ark 1982). Azot kullanim etkinliğini etkileyen faktörleri inceleyen Moll ve ark. (1982), azot kullanım etkinliğinin iyileşebilmesi için hem azot alım etkinliğinin, hem de azot yararlanma etkinfiğinin birlikte iyileșmesi gerektiğini saptamışlardır.

Capuro ve Vos (1981), azot kullanım etkinliğinin iyileşmesi ile daha az azotlu gubre kullanilarak, yüksek verim elde edilebileceğini ve yıkanmayla uzaklaşıp çevre

\footnotetext{
YUZzüncó Yil Üniv, Ziraat Fak. Toprak Bölünü - Van

${ }^{2}$ Karadeniz Teknik Oniv. Ordu Ziraat Fak. Tarla Bitkileri Bölamu - Ordu
} 
kirliliğine yol açan azot miktarının azalabileceğini bildirmişlerdir. Azot kullanım etkinliğini etkileyen ónemli bir faktör de azotun yıkanması ile uzaklașması oldugüundan, azotlu gobrelerin tek dozda verilmeleri yerine bölünerek uygulanmaları. yıkanma kayıplarının azaltımasi, su kaynaklarinın korunmasi, hastalıklara karşı dayanıklilık ve azot kullanım etkinliğinin iyileşmesi bakımından bayok önem taşımaktadır (Darwinkel 1980, Dilz ve ark. 1982). Bu nedenle azot kullanım etkinliģinin artırılması tarımsal Oretimdeki ana hedeflerden biridir.

Tahıllar için azot kullanım etkinliği, olgunluk doneminde tane veriminin, toplam azot alımına (tane+sap) oranı şeklinde tanımlanmaktadir (Isfan ve ark. 1991). Bu değer birim miktar azot alımı tarafindan Qretilen tane verimini ifade etmektedir. Iyì bir genotip. toprak ve gobrelerden yüksek miktarlarda azot alarak, aldığı azotu saptan ziyade daha çok tane verimini artırmak için kullanır.

Bitkinin azotu ne kadar ekonomik kullandığını gösteren bir diğer ólçut ise azot hasat indeksidir. Azot hasat indeksi, hasat döneminde tane azot alıminin toplam azot alimina (tane+sap) orani seklinde tanımlanmaktadır (Graham ve ark. 1983). Dort farkiı bugğday çeşitinde yaptığı araştırmada Birsin (2000), azot alım! ve azot hasat indeksinin çeşitlere göre değiştiğini belirtmiştir. Azot translokasyon etkinliği olarak da ifade edilen azot hasat indeksi, tarla koșullarında yapılan bir denemede tane verimi ile olumlu yönde ilişkili olduğu ve azot hasat indeksindeki artışlarla tane veriminde azalma olmaksızın tane protein oranının artabilecegi saptanmıștır (Oztürk ve Çağlar 1999).

Bu araştırmada dort farkiı tritikale genotipinde farkłı azot dozlarinin azot alımına, azot kullanım etkinliğine ve azot hasat indeksine etkileri ile azot kullanım etkinliği ve tane verimi arasindaki liş̧kilerin belirlenmesi amaçlanmıştır,

\section{Materyal ve Yöntem}

Bu araştırma Yüzúnce Yil Universitesi Zirast Fakültesine ait araştırma ve deneme alanında $1995-1996$ uretim ylínda yürätälmüştar. Denernede kullanilan tritikale genotiplerinin (X Triticosecala Wittmack) katuk numaraları ve pedigrileri Çizelge 1'de verilmiştir.

Deneme tesaduf bloklarında faktoriyel desene göre, dört tekrarlamalı olarak yürútulmuştor. Araştırmada azotlu gubre $0,4,8,12$ ye $16 \mathrm{~kg}$ N/da dozlarında, amonyum sulfat ( $\% 21 \mathrm{~N}$ ) formunda yarısı ekimle beraber kalan yarısı kardeşlenme doneminde verilmiştir. Tam deneme parsellerine sabit dozda $\left(8 \mathrm{~kg} \mathrm{P}_{2} \mathrm{O}_{5} / \mathrm{da}\right)$ fosforlu gubre verilmiştir.

Tritikale hatları $20 \mathrm{~cm}$ sıra arası mesafe ile $1.6 \mathrm{~m} \times$ $6 \mathrm{~m}: 9.6 \mathrm{~m}^{2}$ lik parsellerde yetiştirilmiştir.

Deneme alanı topraklarında banye; Bouyoucous hidrometres) ile (Bouyoucous 1951), eriyebilir toplam tuz; saturasyon çarnurunda kondaktivimetre lle Richard, (1954)'e gore belirlenmiştir. Toprakta $\mathrm{pH}$ : Jackson (1958)'e göre, kireç: kalsimetrik olarak (Allison ve
Moodie 1965), organik madde; modifiye edilmış Walkley Black metodu ile (Walkiey 1947), yarayışi fosfor; sodyum bikarbonat yontemiyle (Olsen ve ark. 1954), değişebilir potasyum (Knudsen ve ark. 1982) ve toplam azot Kjeldahl metoduna gore, Kacar (1994)' un aktardığ gibi yapilmiştır.

Toprak analiz sonuçlarina gore, deneme alanı toprağı kumlu killi tın tekstor sınıfında, pH'sı 7.83, kireç miktarı \%18.5, tuz içeriği $\% 0.026$, organik maddesi $\% 0.46$, toplam $N$ kapsami $\% 0.047$, yarayışlı fosfor miktari 4.6 ppm ve değişebilir pctasyum miktarı $202 \mathrm{ppm}$ olarak belirlenmiştir.

Hasat dóneminde her parselden elinan tane ve sap örnekleri kurutma dolabinda $70^{\circ} \mathrm{C}$ ' de sabit ağırliğa gelinceye kadar bekletilmiştir. Ogutulean bitki orneklerinde toplam $\mathrm{N}$ miktarı Kjeldahl yontemi ile belirlenimiștir (Kacar 1984).

Tane ve sapta $\mathrm{N}$ aiimr; $\% \mathrm{~N}$ içeriklerinin tane ve sap verimleri ( $\mathrm{kg} / \mathrm{da}$ ) ile çarpilarak,

azot alımı: \% $\mathrm{N}$ içerig̈i $x$ verim $(\mathrm{kg} / \mathrm{da})$,

azot kullanim etkinliği; tane verimi, toplam azot alımina (tane+sap) oranlanarak (Isfan ve ark., 1991),

azot kullanım etkinligi: tane verimi (kg/da) / topiam $\mathrm{N}$ alimi $(\mathrm{kg} / \mathrm{da})$,

azot hasat indeksi; tane $\mathrm{N}$ alıminin toplam $\mathrm{N}$ alımina (tane+sap) bölonmesi ile (Graham ve ark., 1983),

azot hasat indeksi: tane $\mathrm{N}$ alimi ( $\mathrm{kg} / \mathrm{da}) \times 100 /$ toplam $\mathrm{N}$ alımi $(\mathrm{kg} / \mathrm{da})$ ile belirlenmiştir.

Araștırmanın yapıldığı yillara ait toplam yağıs miktarı 1995 ve 1996 yıllarında sirasıyla $366.3 \mathrm{~mm}$ ve $389.4 \mathrm{~mm}$ olarak ölçălorken, ayni yillar için sicaklik ortalamalari $9.7^{\circ} \mathrm{C}$ ve $10.3^{\circ} \mathrm{C}$ olarak belirlenmiştir. Uzun yıllar yağıs toplamı $380.4 \mathrm{~mm}$ ve sıcaklık ortalaması ise $8.8^{\circ} \mathrm{C}$ dir (Anonim 1997).

Denemede elde edilen verilerde varyans, regresyon ve korelasyon anslizleri Duzgüneş ve ark.(1987)' nin göre Costat istatistiksel paket programi kullanilarak yapılmıştır.

\section{Bulgular ve Tartışma}

Dört farklı tritikale genotipinde artan azot dozlarin azot içeriğine, alımina, azot kullanım etkinligine ye azot hasat indeksine etkilerine ilişkin varyans analiz sonuçları Çizelge 2' de, bu kriterler için interaksiyon ortalamaları Çizelge $3^{\prime}$ de sunulmuştur. Değişik azotlu gübre dozlari sap ve tanede azot içeriğini istatistiksel olarak çok ônerrli ( $p<0,001)$ dozeyde artırmıştır. Buṇa karşılik, sapta azot içeriğine genotip etkisi önemli görölmemiş ancak, tane azot içeriğine fark! tritikale genotiplerinin ve genotip $x$ azot dozu interaksiyonunun etkisi onnemli bulunmuştur. 
Tane ve sapta azot içeriğine, alimına ve bazı azot kullanım özelliklerine azot dozlarının etkisi ile Duncan gruplandirmaları Çizelge $4^{\prime}$ de, tritikale genotiplerinin etkisi Çizelge $5^{\prime}$ de göralmektedir. Sap ve tanede en duşûk azot içeriği kontrolde $(\% 0.27$ ve \%1.63) belirlenirken, azotlu gübre uygulamalarına bağlı olarak azot içeriği sap ve tanede artmıştır. Her iki bitki kısminda da en yüksek azot içeriğine $12 \mathrm{~kg} \mathrm{~N}$ dozunda (\%0.4 ve $\% 1,91)$ ulaşılmıştır (Çizelge 4). Sapta en daşak azot içerlği 9 nolu tritikale genotipinde saptanırken, 13 nolu genotipte sap $\mathrm{N}$ içeriği $\% \quad 0.37$ olarak bulunmuştur. Benzer olarak, 9 nolu genotipte \% 1.73 olan tane azot içerighi, 10 nolu genotipte \% 1.93'e youkselmiştir. Duncan testi sonuçlarına göre, 7,10 ve 13 nolu tritikale genotiplerinde tane azot içerikleri bakımından ónemli fark bulunmamasına karşılık, 9 nolu genotipte belirlenen azot içeriği diğerlerinden istatistiksel anlamda daşak olmuştur (Çizelge 5).

Yapılan varyans analiz sonuçlarına göre, farklı tritikale genotiplerinde, sap, tane ve toplam azot alımına azotlu gobrelemenin etkisi çok önemli $(p<0.001)$ bulunmuştur. Ancak anılan kriterler üzerine farkı tritikale genotiplerinin etkisi ônemli görülmemiş ve genotip $x$ azot dozu interaksiyonunun sadece toplam azot alimında istatistiksel olarak onemli $(p<0.01)$ olduğu górulmûş̧ur (Çizelge 2).

Sap azot alimi azotlu gubre verilmediğinde $0.73 \mathrm{~kg}$ $\mathrm{N} /$ da olarak belirlenirken, bu miktar $4 \mathrm{~kg} \mathrm{~N}$ dozunda 1.23 $\mathrm{kg} \mathrm{N} \mathrm{Na}$ ve $16 \mathrm{~kg} \mathrm{~N}$ dozunda $1.93 \mathrm{~kg} \mathrm{~N}$ düzeyine youkselmiştir. Tane azot alimi, kontrolde $2.31 \mathrm{~kg}$ olurken, artan azotlu gubre dozlari ile artarak $4 \mathrm{~kg}$ azot dozunda $2.88 \mathrm{~kg}, 12 \mathrm{~kg}$ azot dozunda ise $4.58 \mathrm{~kg}$ duzeyine ulaşmıştır. Duncan testi sonuçlarına góre, kontrol ve $4 \mathrm{~kg}$
$\mathrm{N}$ dozu ayn! grupta yer alırken, 8,12 ve $16 \mathrm{~kg}$ azot dozlarında belirlenen azot alımları bu değerlerden yoksek olarak ikinci bir grubu oluşturmuşlardır (Çizelge 4).

Toplam (sap+tane) azot alımi artan azot dozlari ile düzenli olarak artarak kontrolde $3.04 \mathrm{~kg}$ ve $4,8,12,16 \mathrm{~kg}$ $\mathrm{N} /$ da dozlarında sirasıyla $4.11 \mathrm{~kg}, 5.69 \mathrm{~kg}, 6.50 \mathrm{~kg}$ ve $6.09 \mathrm{~kg}$ olarak befirlenmiştir. En yüksek toplam azot alımina $12 \mathrm{~kg} \mathrm{~N}$ dozunda ulaşıllirken, bu değer kontrol, 4 $\mathrm{kg}$ ve $8 \mathrm{~kg}$ azot dozlarında belirlenen azot içeriklerinden istatistiksel olarak yăksek bulunmuştur (Çizelge 4).

Azot alimina farklı tritikale genotiplerinin etkisi incelendiğinde, en fazla sap azot alımının 13 nolu genotipte olduğu ve tane azot alımının ise 10 nolu tritikale genotipinde daha yôksek olduğu saptanmıştır Benzer olarak toplam azot alımiarinda da, 10 ve 13 nolu genotiplerde azot alımı diğer genotiplerden daha yüksek bulunmuştur (Çizelge 5). Ancak, azot alımı bakımından, genotipler arası fark istatistiksel olarak onemli bulunmamıştır. Genotip x azot dozu interaksiyonunun, toplam azot alımına etkisi onnemli görümüştür. En düşük toplam azot alımlari genotip $\times \mathrm{N}_{0}$ azot dozu interaksiyon gruplarında elde edilirken, 7 nolu genotip $\times 16 \mathrm{~kg} \mathrm{~N}$ dozu, 9 no lu genotip $\times 12 \mathrm{~kg} \mathrm{~N}$ dozu, 10 nolu genotip $\times 12 \mathrm{~kg} \mathrm{~N}$ dozu ve 13 nolu genotip $\times 12 \mathrm{~kg} \mathrm{~N}$ dozu interaksiyon gruplarinda belirienen toplam azot alımiarının daha yúksek olduğu saptanmıştır (Çizelge 2). Kanu ile ilgili olarak, farklı ekolojik koşullarda tritikale ile ilgili yapilan araştırmalarda, azotlu gübreleme ile sap ve tanede azot içeriği ile alımının őnemli duzeyde arttığı belirlenirken (Ellen 1993, Koc ve Szymczyk 1997, Koc ve ark. 1997). Isfan ve ark. (1991) 12 tritikale genotipi ile yürüttukleri denemede, azot alımı bakımından genotipler arası farkın önemli olmadığını bildirmişlerdir.

Çizelge 1. Denemede kuilanilan tritikale hatlarinin pedigri ye orijinleri

\begin{tabular}{|c|l|l|}
\hline Katak no & \multicolumn{1}{|c|}{ Pedigri } & \multicolumn{1}{|c|}{ Orijini } \\
\hline 7 & DRIRA OUT CROSX21295 OAP9 & ICARDA"* \\
9 & YOGU 1 "S"/ ANTEATER 62 CTM 10403-015M OY 2B BY OB & CMMYT** \\
10 & JUANILLO 98-212 OAP & ICARDA \\
13 & HARE 7265/YOGU 1 "S" SWT 1697 05Y-OM OY4M-1YP-OB & CMMYT \\
\hline
\end{tabular}

- Uluslararası Buğday ve Mısır Araştırma Merkezı

*. Ulusiararası Kurak Alanlar Araştırma Merkezi

Çizelge 2. Azot içeriğine, alımına ve bazı $\mathrm{N}$ kullanım özelliklerine tritikale genotipleri ve azotlu gübrelemenin etkisine ilişkin varyans analiz sonuçlan

\begin{tabular}{|c|c|c|c|c|c|c|c|c|}
\hline \multirow[t]{2}{*}{$\begin{array}{l}\text { Varyasyon } \\
\text { kaynağı }\end{array}$} & \multirow[t]{2}{*}{$S D$} & \multicolumn{2}{|c|}{$\mathrm{N}$ içeriğil, \% } & \multicolumn{3}{|c|}{$\mathrm{Nalimi}, \mathrm{kg} \mathrm{N} / \mathrm{da}$} & \multirow[t]{2}{*}{$\begin{array}{c}\text { N kullanim } \\
\text { etkinliğji }\end{array}$} & \multirow[t]{2}{*}{$\begin{array}{l}\text { Nhasat } \\
\text { indeksi }\end{array}$} \\
\hline & & Sap & Tane & Sap & Tane & Toplam & & \\
\hline Bloklar & 3 & 0.82 & 1.03 & 1.30 & 0.06 & 0.71 & 0.74 & 1.23 \\
\hline N Dozlari & 4 & $9.56^{\text {tot* }}$ & $8,95^{\text {*4* }}$ & $152^{\text {*6* }}$ & $20.4^{* * \hbar}$ & $43.9^{\text {twh }}$ & $5.81^{\circ * *}$ & $4.12^{\text {nt }}$ \\
\hline Genotipler & 3 & 0.77 & $5.32^{a=}$ & 0.36 & 1,01 & 0.93 & 0.96 & 1.00 \\
\hline NxGenotip Int. & 12 & 0.82 & $3.79^{*+n}$ & 0.78 & 1.89 & $2.85^{* 4}$ & 1.04 & 1.21 \\
\hline Hata & 57 & & & & & & & \\
\hline Genel & 79 & & & & & & & \\
\hline
\end{tabular}

*t ve *** ile gösterilen F değerleri sırasıyła \%1 ve \%0.1 düzeylerinde önemlidir. 
Çizelge 3. Farkı tritikale genotiplerinde, artan azot dozlarının sap ve tanede azot içeriği, alımı ve bazı azot kullanım özelliklerine etkisi

\begin{tabular}{|c|c|c|c|c|c|c|c|c|}
\hline \multirow{2}{*}{$\begin{array}{c}\text { Tritikale } \\
\text { genotipleri }\end{array}$} & \multirow{2}{*}{$\begin{array}{c}\text { Azot } \\
\text { dozlan }\end{array}$} & \multicolumn{2}{|c|}{ N içeriği, \% } & \multicolumn{3}{|c|}{$\mathrm{N}$ alımı, kg N/da } & \multirow{2}{*}{$\begin{array}{c}\text { N kullanim } \\
\text { etkinliği }\end{array}$} & \multirow{2}{*}{$\begin{array}{l}\mathrm{N} \text { hasa } \\
\text { indeksi }\end{array}$} \\
\hline & & Sap & Tane & Sap & Tane & Toplam & & \\
\hline 7 & 0 & 0.27 & 1.54 & 0.61 & 2.38 & 2.99 & 50.2 & 79.6 \\
\hline 7 & 4 & 0.37 & 2,14 & 1.42 & 3.40 & 4.82 & 32,9 & 70.5 \\
\hline 7 & 8 & 0.35 & 1.83 & 1.62 & 3.62 & 5.24 & 37.3 & 69.0 \\
\hline 7 & 12 & 0.36 & 1.76 & 1.57 & 3.15 & 4.72 & 37.8 & 66.7 \\
\hline 7 & 16 & 0.40 & 1.94 & 2.20 & 4.27 & 6.47 & 34.4 & 66.0 \\
\hline 9 & 0 & 0.30 & 1.66 & 0.81 & 2.41 & 3.22 & 46.4 & 74.9 \\
\hline 9 & 4 & 0.32 & 1.71 & 1.15 & 2.66 & 3.81 & 41.7 & 69.8 \\
\hline 9 & 8 & 0,32 & 1.78 & 1.62 & 3.42 & 5.04 & 37.8 & 67.9 \\
\hline 9 & 12 & 0.40 & 1.80 & 1.84 & 4.79 & 6.63 & 40.8 & 72.2 \\
\hline 9 & 16 & 0.34 & 1.70 & 1.98 & 4.33 & 6.31 & 40.4 & 68.6 \\
\hline 10 & 0 & 0.26 & 1.64 & 0.76 & 2.50 & 3.26 & 45.7 & 76.7 \\
\hline 10 & 4 & 0.37 & 1.89 & 1.29 & 2.84 & 4.13 & 36.2 & 68.8 \\
\hline 10 & 8 & 0.33 & 1.91 & 1.38 & 4.65 & 6.03 & 41.0 & 77.1 \\
\hline 10 & 12 & 0.42 & 2.25 & 2.00 & 5.03 & 7.03 & 31.9 & 71.6 \\
\hline 10 & 16 & 0.36 & 1.94 & 1.69 & 4.03 & 5.72 & 36.9 & 70.5 \\
\hline 13 & 0 & 0.28 & 1,69 & 0.73 & 1.96 & 2.69 & 43.1 & 72.8 \\
\hline 13 & 4 & 0.35 & 1.68 & 1.06 & 2.60 & 3.66 & 41.8 & 71.0 \\
\hline 13 & 8 & 0.40 & 1.99 & 208 & 4.36 & 6.44 & 34.5 & 67.7 \\
\hline 13 & 12 & 0.42 & 1.88 & 2.25 & 5.34 & 7.59 & 38.3 & 70.4 \\
\hline 13 & 16 & 0.39 & 2.04 & 1.86 & 4.00 & 5.86 & 36.4 & 68.3 \\
\hline LSD $(P<0.05)$ & & öd & 0.23 & öd & öd & 1.29 & od & Od \\
\hline
\end{tabular}

öd: Ónemili Değil

Çizelge 4. Tritikale genotiplerinin ortalaması olarak, artan azot dozlarının azot içeriğine, alımına ve bazı azot kullanım czellikjerine etkisi

\begin{tabular}{|c|c|c|c|c|c|c|c|}
\hline \multirow{2}{*}{$\begin{array}{c}\text { Azot dozlar! } \\
\mathrm{kg} \mathrm{N} / \mathrm{da}\end{array}$} & \multicolumn{2}{|c|}{$N$ içeriği, \% } & \multicolumn{3}{|c|}{$\mathrm{N}$ alımı, kg N/da } & \multirow{2}{*}{$\begin{array}{c}\text { N kullanım } \\
\text { etkinliği }\end{array}$} & \multirow{2}{*}{$\begin{array}{l}\mathrm{N} \text { hasat } \\
\text { indeksi }\end{array}$} \\
\hline & Sap & Tane & Sap & Tane & Toplam & & \\
\hline 0 & $0.27 c$ & $1.63 b$ & $0.73 \mathrm{c}$ & $2.31 \mathrm{~b}$ & $3.04 d$ & $46.4 \mathrm{a}$ & $76.0 \mathrm{a}$ \\
\hline 4 & $0.35 \mathrm{~b}$ & $1.85 \mathrm{a}$ & $1.23 \mathrm{~b}$ & $2.88 \mathrm{~b}$ & $4.11 \mathrm{c}$ & $38.2 \mathrm{~b}$ & $70.0 \mathrm{~b}$ \\
\hline 8 & $0.35 b$ & $1.88 a$ & $1.68 \mathrm{a}$ & $4.01 \mathrm{a}$ & $5.69 \mathrm{~b}$ & $37.7 \mathrm{~b}$ & $70.4 b$ \\
\hline 12 & $0.40 \mathrm{a}$ & $1.91 \mathrm{a}$ & $1.92 \mathrm{a}$ & $4.58 \mathrm{a}$ & $6.50 \mathrm{a}$ & $37.2 b$ & $70.2 b$ \\
\hline 16 & $0.37 \mathrm{ab}$ & $1.89 a$ & $1.93 \mathrm{a}$ & $4.16 \mathrm{a}$ & $6.09 \mathrm{ab}$ & $37.0 \mathrm{~b}$ & $68.4 b$ \\
\hline
\end{tabular}

a, b, c, d: Farkı harfle gösterilen ortalamalar arasındaki fark kendi sütununda önemlidir $(p<0.05)$.

Çizelge 5. Azot dozlarını ortalaması olarak farkı tritikale genotiplerinde azot içeriği, alımı ve bazı N kullanım özellikleri

\begin{tabular}{|c|c|c|c|c|c|c|c|}
\hline \multirow{2}{*}{$\begin{array}{c}\text { Tritikale } \\
\text { genotipleri }\end{array}$} & \multicolumn{2}{|c|}{$N$ içeriği, \% } & \multicolumn{3}{|c|}{$\mathrm{N}$ alımi, kg N/da } & \multirow{2}{*}{$\begin{array}{l}\text { N kullanım } \\
\text { etkinliği }\end{array}$} & \multirow{2}{*}{$\begin{array}{l}\mathrm{N} \text { hasat } \\
\text { indeksi }\end{array}$} \\
\hline & Sap & Tane & Sap & Tane & Toplam & & \\
\hline 7 & 0.35 & $1.84 \mathrm{a}$ & 1.48 & 3.36 & 4.84 & 38.5 & 70.4 \\
\hline 9 & 0.34 & $1.73 \mathrm{~b}$ & 1.48 & 3.52 & 5.00 & 41.4 & 70.7 \\
\hline 10 & 0.35 & $1.93 \mathrm{a}$ & 1.42 & 3.81 & 5.23 & 38.3 & 72.9 \\
\hline 13 & 0.37 & $1.86 \mathrm{a}$ & 1.60 & 3.65 & 5.25 & 38.8 & 70.0 \\
\hline
\end{tabular}

a, b: Farklı harfle gösterilen ortalamalar arasındaki fark kendi sotununda önemlidir $(p<0.05)$.

Tritikalede azot kullanım etkinliğine farkh azot dozlarının etkisi çok önemli $(p<0.001)$ bulunurken, genotip etkisi ile genotip $x$ azot interaksiyonunun etkisi onnemli görälmemiştir (Çizelge 2). Tritikaleye artan dozlarda. azotlu gübre verildiğinde en yáksek azot kullanım etkinliği kontrolde (46.4) belirlenmiştir. Buna karşılık, artan azot dozlarına bağlı olarak azot kullanim etkinliğinde önemli daşusşler görülmüş ve en dussak azot kullanım etkinliği en yüksek azotlu gübre dozunda $(37,0)$ belirlenmiştir (Çizelge 4)
Yăksek azotlu gübre dâzeylerinde azot kullanım etkinliğinin azalması konuyla ilgili yapılan pek çok araștırma bulgusu ile uyum içerisindedir (Moll ve ark. 1982, Isfan 1990, Eagle ve ark. 2000, Ortega ve ark. 2000). Guiliard ve ark. (1995) çavdar - misır ürün deseninde en yüksek azot kullanım etkinliğinin $11.2 \mathrm{~kg}$ $\mathrm{N} / \mathrm{da}$ azot dozunda 40 olarak belirlendiğini ve artan azot dozları ile bu oranın düştūganuo, Koc ve Szymczyk (1997) azotlu gübreleme ile tritikalede azot kullanım etkinliğinin 59.8'ten $34.4^{\prime}$ 'e düştugônū bildirmişlerdir. 
Azot kullanım etkinliğine genotip etkisi incelendiğinde, en yaksek azot kullanım etkinliğinin 9 nolu tritikale genotipinde $(41,4)$ elde edildiği ve diğer genotiplerin azot kulianım etkinliklerinin birbirine oldukça yakın olduğu belirlenmiştir (Çizelge 5). Ancak, azot kullanım etkinliği bakımindan, denemeye alınan genotipler arası fark istatistiksel olarak önemli bulunmamıştır. Cieply ve Oracka (1996) 46 tritikale genotipini besin çözeltisinde yetiştirerek yürüttakleri denemede, azot kullanımı yönünden genotipler arası bāyük farklar olduğunu saptamışlardır. Isfan ve ark. (1991) farklı tritikale genotiplerinde yaptıkları araştırmada azot kullanım etkinliğinin 32.1 ile 41.9 arasında değiştiğini, Raun ve Johnson (1999) maksimum verim elde edebilmek için azotlu göbre yüksek dozlarda verildiğinde azotun önemli bir kısmının yıkanmayla, gaz halinde ve yüzey akışla uzaklaştığını ve tahıllarda azot kullanım etkinliğini yaklaşık 33 olduğunu belirlemişlerdir. Buna göre, araştırmamızda farklı tritikale genotiplerinde belirlenen azot kullanım etkinliğinin literatărde bildirilen değerlerle uyum içerisinde olduğu anlaşılmaktadır.

Yapilan varyans analizi sonucu, farkli dozlarda verilen azotlu göbrenin azot hasat indeksine etkisinin önemli olduğu $(p<0.01)$ saptanmıştır (Çizelge 2). Azot hasat indeksi azotlu göbrenin kontrol dozunda 76.0 olarak belirlenirken, artan azot dozları ile düzenli olarak azalarak $16 \mathrm{~kg} \mathrm{~N} /$ da azot dozunda 68.4 'e düşmüştôr. Duncan testi sonuçlarına göre, $4,8,12$ ve $16 \mathrm{~kg} \mathrm{~N} / \mathrm{da}$ azot düzeyleri birbirlerinden istatistiksel olarak farksız bulunmasına karşılık, kontrolde belirlenen azot hasat indeksi bu uygulamalardan ơnemli düzeyde yüksek bulunmuştur (Çizelge 4). Kandil (1984), azotlu gübreleme ile azot hasat indeksinin önemli düzeyde değişmediğini ve yaklaşık 65 olduğınu bildirmiştir.
Azot hasat indeksine tritikale genotiplerinin etkisi istatistiksel olarak önemli olmamıştır. En yoksek azot hasat indeksi, 10 nolu tritikale genotipinde 72.9 olarak hesaplanmıștır. Azot hasat indeksi, 7,9 ve 13 nolu tritikale genotiplerinde ise sırasıyla, $70.4,70.7$ ve 70.0 olarak saptanmıștır. Ancak, genotipler arası bu farklılıkların önemli olmadığı belirlenmiştir. May ve ark. (1991) azot hasat indeksinin farklı buğday çeşitlerinde 49 ile 81 arasında değiştiğini, Ellen (1993), tritikalede yürüttugo araştırmada azot hasat indeksinin çeşitlere göre değiştiğini ve ortalama 84.7 olduğunu bildirmiştir. Birsin (2000), buğdayda ikì yıl süreyle yaptığı tarla denemesinde, azot hasat indeksine çeşit etkisinin birinci deneme yılında onemli olmadığını ancak, ikinci deneme yılinda azot hasat indeksinin buğday çeşitlerine gorre önemli dazeyde değiştiğini saptamıştır.

Farklı azotlu gübre dúzeylerinde azot kullanim etkinliği ile tane verimi arasındaki ilișkiler Şekil 1, 2 ve 3 'te görölmektedir. Her üç şekilde de azot kullanım etkinliği ile tane verimi arasında önemli ilişkilerin bulunduğu belirlenmiştir.

Bu ilişki kontrolde ( $\left.r=0.763^{* * *}\right)$ ve $4-8 \mathrm{~kg} \mathrm{~N} / \mathrm{da}$ azot uyguiamalarında ( $r=0.563^{* * *}$ ) \%0.1 dazeylerinde onemli bulunurken, 12 ve $16 \mathrm{~kg} \mathrm{~N} / \mathrm{da}$ azot dozlarında bu ilişki \%5 dozeyinde önemli bulunmuştur. Yani, azot kullanım etkinliği ile tane verimi arasındaki ilişki yüksek azot dozlarında zayıflamıştır. Elde edilen bu sonuçlar Isfan ve ark. (1991)'in bulguları ile uyum içerisindedir. May ve ark. (1991) buğdayda tane verimi ile azot kullanım etkinliği arasında önemli düzeyde $\left(r=0.99^{* *}\right)$ iliş̧ki bulunduğunu saptamışlardır.

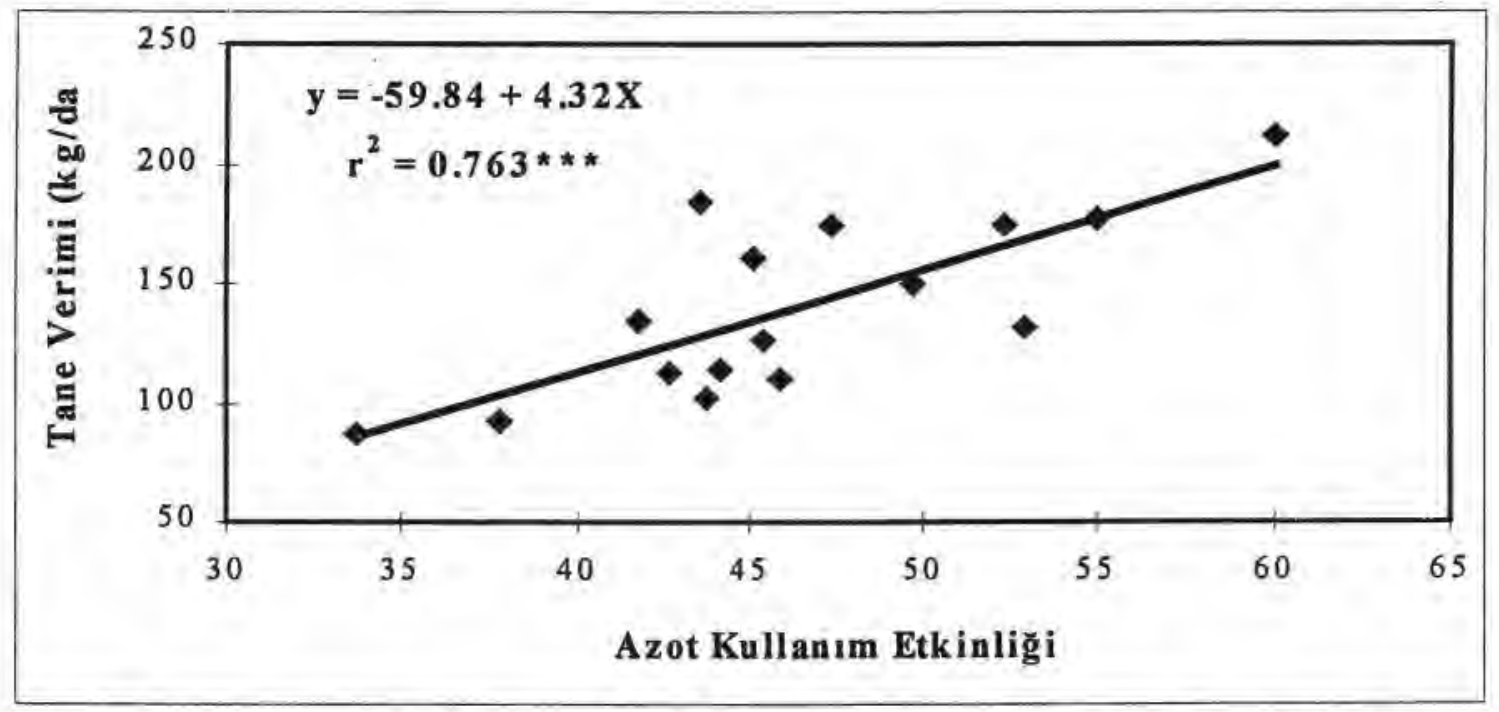

Şekil 1. Dört tritikale genotipinin ortalaması olarak, azotlu găbre uygulanmadığında (kontrol) azot kullanım etkinliği ile tane verimi arasındaki ilișki 


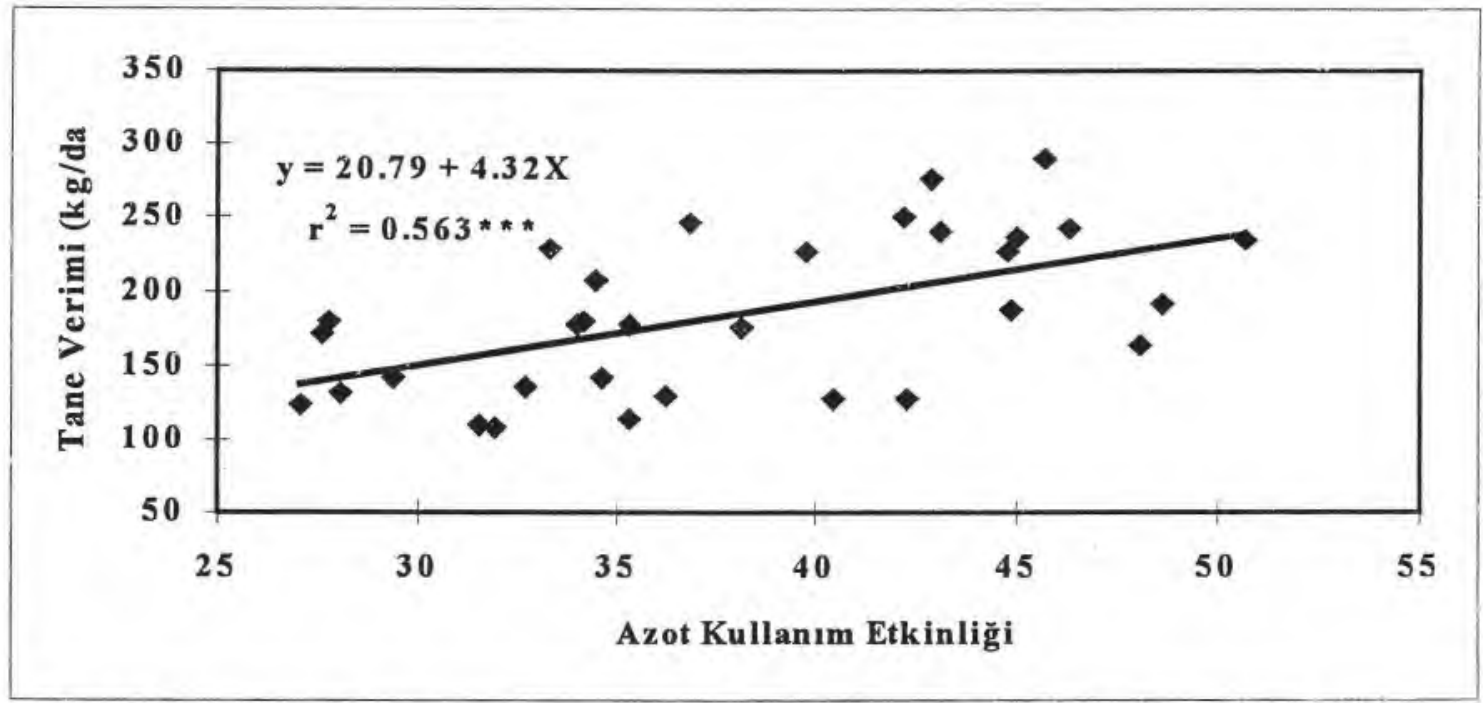

Şekil 2. Tritikale genotiplerinin ortalaması olarak, orta düzeyde azotlu gübre uygulamasında ( $4 \mathrm{ve} 8 \mathrm{~kg} \mathrm{~N} / \mathrm{da}$ ) azot kullanım etkinliği ile tane verimi arasındaki ilişki

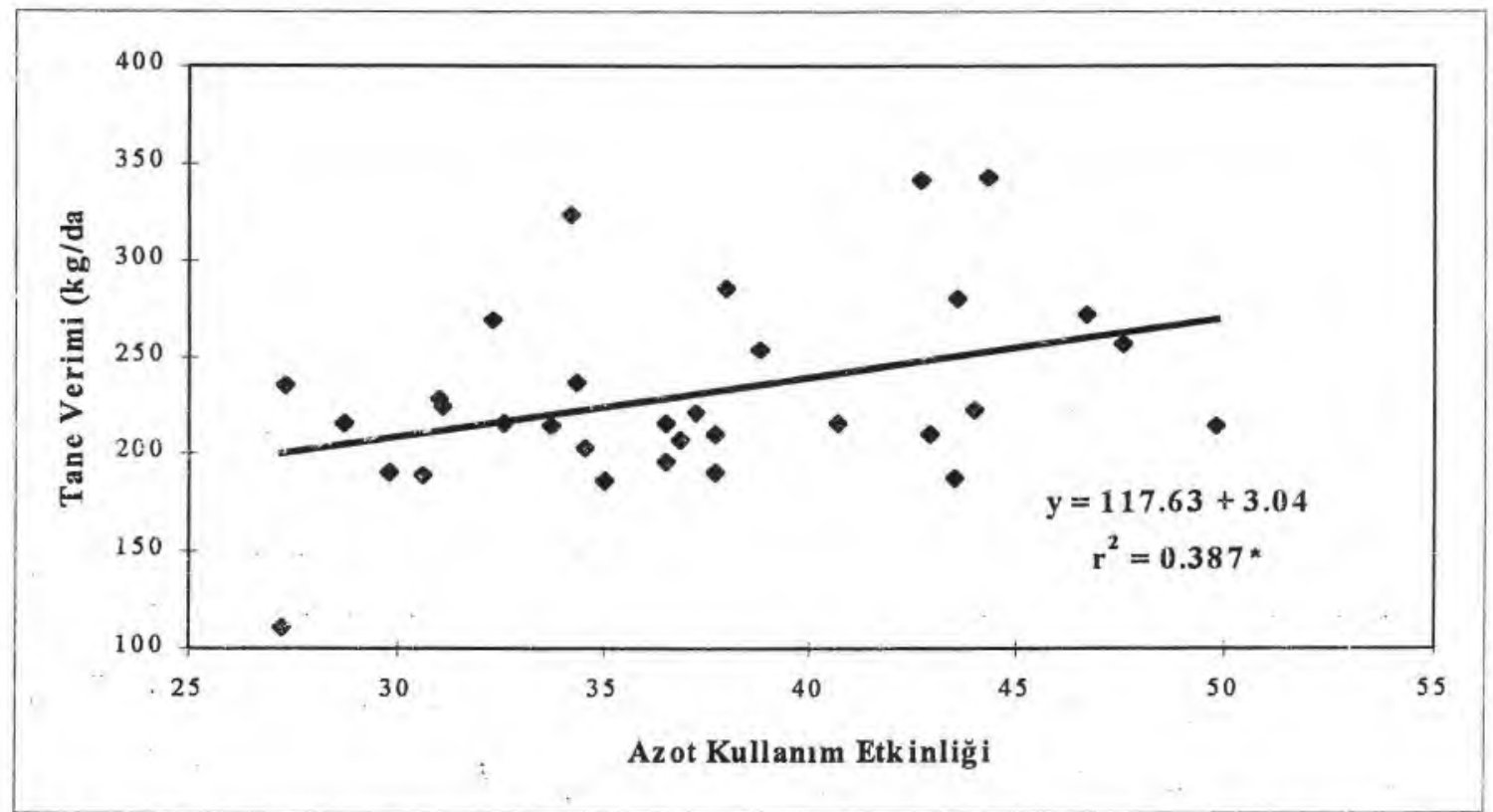

Şekil 3. Tritikale genotiplerinin ortalaması olarak, yüksek azot dozu uygulamasinda (12 ve $16 \mathrm{~kg} \mathrm{~N} / \mathrm{da}$ ) azot kullanım etkinliği ile tane verimi arasındaki ilişki

\section{Sonuç}

Farklı tritikale genotiplerinin kışlık olarak yetiştirildiği bu araştırmada, azotlu gübrelemenin sap ve tanede azot içeriğine, alımına, azot kullanım etkinliğine ve azot hasat indeksine etkisi istatistiksel olarak çok önemli olmuştur. Tane azot içeriği, tane azot alımı ve toplam azot alımlarının $12 \mathrm{~kg} \mathrm{~N} / \mathrm{da}$ azot düzeyinde en yüksek olduğu belirlenmiştir. Azot kullanim etkinliği ve azot hasat indekslerinin kcntrolde en yüksek olduğu ve artan miktarlarda verilen azotlu gübrenin etkin ve €konomik bir şekilde kullan:Imayarak bu kriterleri azaltt!ğı görülmüştür. Bu kriterler üzerine, azotlu gübrenin uygulama düzeyinden ayrı olarak, genotip etkisinin, azotun bölünerek uygulanmasının ve yağıș rejiminin de etkili olduğu sanılmaktadır.

Denemede incelenen özelliklerden sadece tane azot içeriğinde genotip etkisi önemli bulunurken, diğer özeiliklere tritikale genotiplerinin etkisi c̈nemli olmamıştır. Azot dozu $x$ genotip interaksiyonu tane azot içeriği ve toplam azct alımlarında önemli bulunmuştur. Yapılan regresyon ve korelasyon analizleri ile azot kullanım etkinliği ve tane verimi arasında önemli ilişkiler saptanmıştır. Bu ilişkinin kontrol ve düşük azotlu gübre düzeylerinde daha kuvvetli olduğu görülürken, yüksek azot düzeylerinde bu ilişki zayıflamıştır. 


\section{Kaynaklar}

Allison, L. E. and C.D. Moodie, 1965, Carbonate in: C.A. Black et. a. (Ed.) Methods of Soil Analysis. Part 2. Agronomy: 13791400. Am. Soc. of Agron., Inc., Madison Wisconsin USA.

Anonim, 1997, Van Meteoroloji Bölge Müdüriügú kayıttari.

Birsin, M. A. 2000. Buğdayda azot alimı ve azot hasat indeksi. Ankara Univ. Z. F.,Tarim Bilimleri Dergisi, 6 (3) 27-31.

Bouyoucous, G. D: 1951. A Recalibration of the hydrometer method for making machanical analysis of the soil. Agronomy $\mathrm{J}_{4,43} 43$ $434-438$

Capuro, E. and R. Vos, 1981. An index of nutrient efficiency and its application to corn yield response to fertilizer, I. Derivation. estimation and application. Agronomy J, 73 128-135.

Cleply, J. and T, Oracka, 1996. Nitrogen utilization efficiency in winter triticale. Plant Breeding and Seed Science, 40 (1-2) $117-124$

Darwinkel, A. 1980. Grain production of winter wheat in relation to nitrogen and diseases. II. Relationship between nitrogen dressing and yellow rust infection. Zeitschrift for Acker und Pflanzenbau, 149 299-308.

Dilz, K., A. Darwinkel, R. Boon and L. J. L. Verstraeten, 1982. Intensive wheat production as related to nitrogen fertilization, crop production and soil nitrogen; experience in the Benelux. The Fertillzer Society, London, s, 93-149.

Düzgüneș, O., T.Kesici, O. Kavuncu ve F. Gürbaz, 1887. Araștirma ve Deneme Metotları (Istatistik Metotları-1), A, Ó. Z. F Yayinları: 1021, Ankara, 381s,

Eagle, J. A., J. A. Bird, W. R. Horwath, B. A. Linquist, S. M. Brouder, J. E. Hill and J. V. Kessel, 2000. Rice yield and nitrogen utilization efficiency under alternative straw management pratices. Agronomy J, 92 1096-1103.

Ellen, J. 1993. Growth yield and composition four Winter cereals. II. Nitrogen and carbohydrate economy. Netherlands Journal of Agricultural Science; 41 235-546.

Graham, R. D. P. E. Geytenbeek and B. C. Radelifie, 1983 Responses of triticale, wheat, rye, and barley to nitrogen fertilizer. Australian Journal of Experimental Agriculture and Animal Husbandry, 23 73-79.

Guillard, K, G. F. Griffin, D. W. Allinson, M. M. Rafey, W. R. Yamartino and S. W. Pietrzyk, 1995. Nitrogen utilization of selected cropping systems in the U.S. Northeast: I. Dry matter yield, $\mathrm{N}$ uptake, apparent $\mathrm{N}$ recovery and $\mathrm{N}$ use efficiency. Agronomy J, 87 193-199.

Isfan, D. 1990 . Nitrogen physiological efficiency index in some selected spring barley cultivars. J. Plant Nutrition, 13907 914.

Isfan, Di, I. Csemi and M. Tabi, 1991. Genetic variation of the physiological efficiency index of nitrogen in triticale. $d$. Plant Nutrition, 14 (12) $1381-1390$

Jackson, M. 1958. Soil Chemical Analysis. P. 1-498. Prentice-Hall, Inc. Englewood Cliffs, New Jersey, USA.
Kacar, B. 1984. Bitki Besleme Uygulama Kolavuzu. A.U.Z.F. Yay. 900, Uygulama Kilavuzlarr: 214, Ankara, 140s.

Kacar, B. 1994. Bitki ve Toprağın Kimyasal Analizleri: III. Toprak Analizleri: A.U.Z.F. Eğitim Araştımma ve Geliş̧̦irme Vakfı Yayinlari No: 3, Ankara, 705s.

Kamprath, E. J., R. H. Moll and R. Rodriguez, 1982. Effects of nitrogen fertilization and recurrent selection on performance of hybrid populations of corn. Agronomy J, 74 955-958.

Kandil, A. A. 1984. Response of some sunflower cultivars to different fertility levels. J. Agronomy and Crop Science, 153 $401-406$

Knudsen, D., G. A. Peterson and P. F. Pratt, 1982. Lithium, Sodium and Potassium. Methods of Soil Analysis, Part 2. Chemical and Migrobiological Properties. Agronomy Monograph No:9 (2 nd Ed.) ASA-SSSA, Madison, Wisconsin. USA.

Koc, J. and S. Szymczyk, 1997, Winter triticale yield after fertilizing with nitrogen depending on liming level. Zeszyty-NoukoweAkademil Rolnlczel-w-Szczecinie, Rolnictwo, 65 177-182,

Koc, J., T. Wojnowska, D. Pilejczyk and S. Szymczyk, 1997. The content and yield of spring triticale protein on light soil depending on the agrotechnics used, Zeszyty-NoukoweAkademii Rolniczej-w-Szczecinie, Rolnictwo, 65 183-188.

May, L, D. A. V. Sanford, C. T. Mackown and P. L. Cornellus, 1991. Genetic variation for nitrogen use in soft red $X$ hard red winter wheat populations. Crop Science, 31 626-630.

Moll, R. H. E. J. Kamprath and W. A. Jackson, 1982. Analysis and interpretation of factors which contribute to efficiency of nitrogen utilisation. Agronomy J, 74 562-564

Oisen, S. R., A. V. Cole, F. S. Watanable and L. A. Dean, 1954. Estimation of Available Phosphorus in Soil by Extracting with Sodium Bicarbonate. U.S. Dept. of Agric Circ. 939. Washington D.C.

Ortega, A. L., K. D. Sayre and C. A. Francis, 2000. Wheat nitrogen use efficiency in a bed planting system in northwest Mexico. Agronomy J, 92 303-308.

Ozturk, A. ve Ö. Çağlar, 1999. Arpa genotiplerinde azot etkiniik indeksieri tane verimi ve tane protein oranı arasindaki ilișkiler. A. O. Z. F.,Tarim Bilimieri Dergisi, 5 (3) 102-109.

Raun, W. R, and G.V. Johnson, 1999. Improving nitrogen use efficiency for cereal production. Agronomy J, $91357-362$.

Richards, L. A. 1954. Diagnosis and Improvement of Saline and Alkaline Soils. Handbook. 60. US. Dept. Of Agriculture.

Tilman, B. A. W. L. Pan and S. E. Ulrich, 1991. Nitrogen use by northern adapted barley genotypses under no-till. Agronomy J., 83 194-201.

Walkley, A. 1947. A Critical examination of arapid method for determining organic carbon in soils effect of variations in digestion conditions and inorganic soil constituents. Soil Science, 63, 251-263.

Yağbasanjar, T, ve A. C. Ölger, 1989. Tritikale (Xtriticosecale wittmack) nin besin değeri ve önemi. Ç.U.Ziraal Fakültesi Dergisi, 4 (4) 120-128. 